\title{
Changes in Fish Quality During Canning Process and Storage Period of Canned Fish Products: Review Article
}

\author{
Adel A El Lahamy* and Hassan R Mohamed \\ National Institute of Oceanography and Fisheries, Fish Processing Technology Laboratory, Egypt.
}

*Corresponding author: Adel A El Lahamy, National Institute of Oceanography and

Fisheries, Fish Processing Technology Laboratory, Egypt.

Received Date: March 09, 2020

Published Date: August 10, 2020

\begin{abstract}
Fish and fish products are subject to enzymatic, microbiological and chemical changes during fish processing. Canned fish products stable at ambient temperature, have long shelf life and in consequence are eminently suitable for world-wide distribution. Therefore, this study aimed to conclude the alterations in proximate chemical composition, Quality characteristics, nutritional quality and microbiological safety of fish during canning process. Also following changes in these parameters during storage period of canned fish.
\end{abstract}

Keywords: Canning process; Chemical composition; Storage period

\section{Introduction}

Canning is a well-established and traditional means of providing food which is stable at ambient temperatures, has long shelf life and in consequence is eminently suitable for world-wide distribution. Canned fish is therefore exported from countries all over the world into the consumer markets. The manufacturing of canned fish has provided, and continues to provide much-needed employment, individual incomes and the means for foreign currency exchange for developing countries, particularly in Southeast Asia, South America and the Indian Ocean. [1] Canned fishery products are formally canned in vegetable oils and now available in water packs. Preservation methods such as freezing, and canning are technologies that used basically due to cost and non-availability of equipment and cold storage system [2]. The advantages of canned food are such as their preservation, safety and convenience. The major steps in canning process include cooking, cooling, packing with a covering oil or tomato sauce in sealed cans and sterilized to achieve commercial sterilization by the heat. Oxidation of lipids and formation of nitrogenous compounds can occur during the cooling step of fish cooking [3]. during storage temperature (above $35^{\circ} \mathrm{C}$ ) must be avoided to prevent the growth of thermophilic bacterial spores. Changes in the food quality during storage period result from a change in physicochemical and microbiological properties that decrease their nutritional value, palatability, and safety.

\section{Chemical Composition}

Slabyj and Carpenter [4] stated that raw mussel meat contained $81.2 \%$ moisture, $3.29 \%$ protein, $0.81 \%$ lipid, $0.41 \%$ ash, and $0.75 \%$ carbohydrate, steamed mussel meat contained $74.6 \%$ moisture, $2.73 \%$ protein, $0.62 \%$ lipid, $0.24 \%$ ash, and $0.32 \%$ carbohydrate, and canned mussel meat contained $75.7 \%$ moisture, $2.90 \%$ protein, $0.72 \%$ lipid, $0.27 \%$ ash, and $0.20 \%$ carbohydrate. El-Sherif (2001) [5] stated that the moisture contents of shrimp canned with vegetables and those canned with tomato sauce were lower by 12.6 and $10.8 \%$ respectively as compared with moisture content of raw shrimp. Also, he found that protein content in shrimp and found that protein contents of raw shrimp, samples canned with vegeta- 
bles and samples canned with tomato sauce were 76.90, 60.85 and 68.11 (on dry weight basis), respectively. These values indicated that heat treatments applied in canning process resulted in losses of protein which were accounted by 20.9 and 11.4 in samples canned with vegetables and tomato sauce respectively. Chemical analysis of canned shrimp showed that crud fat, crud ash and carbohydrate content were higher than of raw shrimp [5]. The chemical composition of smoked mussels of (Mytilus galloprovincialis $L$ ) were $20.4 \pm 0.45,4.9,1.30,2.4 \pm 0.02$ and $69.4 \pm 0.23$ for Protein, lipid, ash and moisture respectively. After caning process these values changed to $12.7 \pm 0.46,8.1 \pm 0.14,3.1 \pm 0.14$ and $70.2 \pm 0.62$ for Protein, lipid, ash and moisture respectively [6]. Also he reported that chemical composition of mussels (Mytilus galloprovincialis L) were $17.3 \pm 0.04,4.0 \pm 0.28,1.8 \pm 0.19$ and $73.0 \pm 0.07$, after caning process these values changed to $12.2 \pm 0.47,10.6 \pm 0.572 .8 \pm 0.01$ $71.1 \pm 0.29$ for Protein, lipid, ash and moisture, respectively. Shakila, et al., (2005) [7] have observed a reduction of $6 \%$ moisture content in cooked tuna. Also, Garcia-Arias et al., (2003) [8] have reported that moisture content decreased and fat content increased in cooked fish fillets. Selmi, et al. (2008) [3] the lipid contents found in tuna (Thunnus thynnus) and sardine (Sardina pilchardus) contents dropped significantly $(\mathrm{P}<0.05)$ after the caning process. In cooked tuna, the moisture content decreased significantly $(p<0.05)$ with an increase in the duration of heat process giving up to $16 \%$ reduction [9]. Canning process reduced the protein content for Orcynopsis unicolor, But, increased in protein content for Euthynnus affinis. El-Dengawy, et al. (2012) [10] determined the chemical composition of Sixteen samples of canned fish products imported (canned tuna, canned sardine, canned Mackerel) and observed that moisture percentages in all canned fish samples ranged between $52.41 \pm 0.035$ to $78.53 \pm 0.142 \%$. It could be observed that all canned fish samples had high values of water activity (0.990-0.999). Meanwhile, $\mathrm{NaCl}$ content ranged between $0.13 \pm 0.000$ to $1.20 \pm 0.042 \%$. Czerner, et al. (2015) [11] determined that the chemical composition of fresh anchovy were $77.65 \pm 0.67,16.24 \pm 0.82,4.25 \pm 0.09$ and $1.16 \pm 0.06$ for moisture content, protein content, lipid content and ash content respectively. In canned fish, chemical composition were $64.82 \pm 0.06,26.74 \pm 0.74,6.23 \pm 0.38$ and $2.21 \pm 0.01$ respectively. Sajib (2015) [12] Studied the effect of canning process on the chemical composition of chela (Laubuka dadiburjori) and determined that moisture content, protein content, lipid content, ash content and carbohydrate content of fresh fish were $76.56 \pm 1.62$, $13.74 \pm 1.22,4.25 \pm 0.85,2.37 \pm 0.56$ and $1.41 \pm 0.79$ respectively. After canning process these values changed to $67.15 \pm 1.69,16.68 \pm 0.88$, $5.46 \pm 0.34,8.15 \pm 0.83$ and $1.35 \pm 0.07$ for Moisture, Protein, Lipid, Ash $t$ and Carbohydrate respectively.

Fatma Arfat (1994) [13] found that the moisture, sodium chloride and protein contents of canned sardine and mackerel were decreased after 24 months storage at room temperature while, total lipids contents was increases. Ghaly (1995) [14] pointed out that chemical composition of canned shrimp was affected by storage at room temperature for 6 months and the kind of filling medium. Moreover, moisture, protein and carbohydrates were decreased while, fat and ash were increased in canned bosr and shrimp packed by dry method. On the other hand the moisture, fat and ash contents were increased. Abd El-Ghafour (1999) [15] found that moisture contents of Tilapia fish fillets slightly decreased while crude protein contents was considerably reduced but crude fat and ash contents were progressively and gradually increased during storage of ambient temperature. Ibrahim (1999) [16] mentioned that moisture, protein and fat contents of canned sardine showed a gradual decreasing as a period of storage at room temperature extended up to 12 months while, ash and salt contents showed a noticed increase. The chemical composition of canned chela ( $\mathrm{Lau}$ buka dadiburjori) fish were $76.56 \pm 1.62,13.74 \pm 1.22,4.25 \pm 0.85$, $2.37 \pm 0.56$ and $1.41 \pm 0.79$ at zero time of storage period. After 30 day of storage period these values changed to $68.13 \pm 2.06,15.15 \pm 0.95$, $5.51 \pm 0.56,10.43 \pm 0.91$ and $1.36 \pm 0.09$. At the end of storage 60 days these values were $68.88 \pm 1.89,15.62 \pm 0.45,5.96 \pm 0.48,12.60 \pm 1.12$ and $1.39 \pm 0.07$ for moisture content, protein content, lipid content, ash content and carbohydrate content respectively [12].

\section{Quality Characteristics}

\section{Total volatile basic nitrogen (TVB-N) and Trimethyleamin (TMA-N)}

TMAO can be degraded during the thermal processing to disagreeable molecules such as TMA and DMA [5,17]. The cooking process had no significant effect on the TVB-N levels $(\mathrm{P}<0.05)$, while TMA-N levels in sardine increased to reach $6.32 \mathrm{mg} / 100 \mathrm{~g}$ [3]. El-Dengawy, et al. (2012) [10] determined the quality characteristics in Sixteen samples of canned fish products imported (canned tuna, canned sardine, canned Mackerel) and observed that TVN values in canned fish samples ranged between 7.01 $\pm 0.254 \mathrm{mg} \mathrm{N} / 100 \mathrm{~g}$ sample to $18.04 \pm 0.593 \mathrm{mg} \mathrm{N} / 100 \mathrm{~g}$ sample. The TVB-N in fresh chela (Laubuka dadiburjori) fish recorded $7.10 \mathrm{mg} \mathrm{N} / 100 \mathrm{~g}$, these values increased to $15.50 \mathrm{mg} \mathrm{N} / 100 \mathrm{~g}$ after caning process [12].

Increasing the total volatile basic nitrogen was attributed to the degradation of nitrogenous compounds resulting in an increase in both trimethylamine nitrogen (TMAN) and ammonia nitrogen $\left(\mathrm{NH}_{3} \mathrm{~N}\right)$ which were considered the principle fractions of the TVBN [13]. The total volatile nitrogen contents of canned shrimp and bosr packed by dry method and in 3\% salt solution, slightly increased during storage at ambient temperature for 6 months [14]. Abd El-Ghafour (1999) [15] recorded a gradual increase in the TVBN content of canned Tilapia fish fillets products as the storage period was extended. At the end of 12 months storage, samples steamed and canned in oil or tomato sauce showed an increasing of TVBN determined by 15.58 and $17.05 \%$ respectively while, the increasing rates were 18.71 and $20.61 \%$ in samples fried and canned in the same filling media respectively. Fatma Arfat (1994) [13] observed a gradual increase in TMA contents of canned mackerel and sardine samples as the time of storage at ambient temperature was extend- 
ed which was attributed to tri-methyl nitrogen oxide that natural present in fish tissue which chemically reduced by SH group existing in fish protein or by zinc present in C-Enamle used for varnishing the cans. Ibrahim (1999) [16] found that the highest increased observed in TMAN content of sardine during storage was found in samples canned with sauce comparing with those packed in oil or spices. The total volatile basic nitrogen of canned sardine packed in different media gradually increased as the period of storage at room temperature was progressed [16]. In the first period of storage (3 months), TVB-N and TMA-N values increased significantly to attain 23.85 and $18.42 \mathrm{mg} / 100 \mathrm{~g}$, and 7.95 and $8.11 \mathrm{mg} / 100 \mathrm{~g}$ in sardine and tuna, respectively, and remained statistically constant $(\mathrm{P}<0.05)$ until the end of the storage period [3]. The TVB-N values of canned chela (Laubuka dadiburjori) fish was $15.50 \mathrm{mg} \mathrm{N} / 100 \mathrm{~g}$, at zero time of storage period. It increased up to $17.68 \mathrm{mg} \mathrm{N} / 100 \mathrm{~g}$ after 30 days. After that it continued to increase to $21.95 \mathrm{mg} \mathrm{N} / 100$ $\mathrm{g}$ after 60 days of storage period [12].

\section{Thiobarbituric acid (TBA) and Peroxide value (PV)}

Primary (peroxide value; conjugated dienes) and secondary (TBA and carbonyl values) lipid oxidation detections did not afford accurate methods for testing quality differences in canned products [18]. Chia, et al. (1983) [19] reported that canning process of rainbow trout pollok and shrimp resulted in reduction of thio-barbituric acid by about $50 \%$ of its initial value in the raw materials. The evaporation of water and loss of juiciness during cooking might have also contributed to an increase in TBA-RS values after cooking [20]. Koizumi, et al. (1987) [21] have also reported that TBA-RS values increased during cooking of fish at $100^{\circ} \mathrm{C}$ for $30 \mathrm{~min}$, but they were below $1 \mu \mathrm{g}$ of malonaldehyde/g of fat. Thio-barbituric acid determined as malon aldhyde slightly increased from $0.40 \mathrm{mg} / \mathrm{kg}$ of raw shrimp to $0.44-0.48 \mathrm{mg} / \mathrm{kg}$ of the canned samples. This could be attributed to slight oxidation of unsaturated fatty acids found in shrimp during heat treatment of canning process [5]. El-Dengawy, et al. (2012) [10] determined the quality characteristics in Sixteen samples of canned fish products imported (canned tuna, canned sardine, canned Mackerel) and observed that acid value of canned fish samples had the highest value of AV being $20.39 \pm 0.000 \mathrm{mg}$ $\mathrm{KOH} / \mathrm{g}$ oil in $\mathrm{CM}$.

It is well-known that the quality of canned products has a very close relationship with their lipid content and composition. Canned fishery products are especially susceptible to flavor and other changes due to the high levels of polyunsaturated fatty acids [22]. Ghaly (1995) [14] observed a gradual increase in TBA value of canned Suez Shrimp and elongated boor samples as the period of storage at ambient temperature was prolonged. Ibrahim (1999) [16] who noticed that TBA values of canned sardine products were gradually decreased as storage period extended and samples canned with sauce showed the lowest TBA values. Abd El-Ghafour (1999) [15] reported that a progressive increment in the TBA value of canned Tilapia fish fillets during storage at ambient temperature for 12 months. Selmi, et al. (2007) [3] studied the effect of local canning process and storage time (up to 6 months) on tuna and sardine canned in olive oil and tomato sauce and found that the PV and TBA index increased significantly in tuna.

\section{pH}

$\mathrm{pH}$ values of raw shrimp, canned shrimp with vegetables and canned shrimp with tomato sauce were $6.27,6.61$ and 6.48 respectively. The higher PH values observed in canned samples may by due to the formation and accumulation of some dibasic amino acid and volatile basic nitrogenous compounds such as NH3 as a result of breakdown and proteolysis of proteins during heat treatment [5]. The $\mathrm{pH}$ value of fresh chela chela (Laubuka dadiburjori) fish was 6.8. Drop off $\mathrm{pH}$ value after caning process to 5.9 in canned fish [12]. Czerner et al. (2015) [11] studied the effect of canning process on physicochemical of anchovy (Engraulis anchoita) and determined that $\mathrm{pH}$ value of fresh fish was 6.07, after canning slightly increased to 6.12 .

Fatma Arfat (1994) [13] observed that $\mathrm{pH}$ values of canned sardine and mackerel products were increased during storage at room temperature due to protein degradation into basic products such as ammonia, amines and hydrogen sulphide. Ghaly (1995) [14] showed that $\mathrm{pH}$ values of canned Suze Shrimp and bosr in dry pack or in 3\% salt solution were slightly decreased during storage at room temperature for 6 months to 6.25 and 6.30 under the same condition. Abd El-Ghafour (1999) [15] during storage of canned Tilapia fish fillets at room temperature, the highest $\mathrm{pH}$ value was found in samples fried and canned in tomato sauce. Ibrahim (1999) [16] noticed a significant increase in $\mathrm{pH}$ value of canned sardine packed in oil, while samples packed in sauce showed a decreasing trend as the period of storage at room temperature was extended [12]. Studied the effect of storage period on the quality of canned chela (Laubuka dadiburjori) and found that the PH value 5.9, 6 and 6.2 for 0,30 and 60 day of storage period.

\section{Nutritional Quality}

\section{Fatty acid}

Aubourg, et al. (1989) [18] reported a slightly higher value in certain fatty acids of cooked tuna. Also observed a significant decrease in C20:5 and C22:6 on cooking of albacore tuna. The cooking process (caning) had a significant effect $(\mathrm{P}<0.05)$ on SFA composition in tuna flesh lipids. The content of C14:0, C18:0 and C20:0 significantly changed; however, unsaturated fatty acids remained constant after processing [3]. The SFA, MUFA and PUFA contents of raw tuna were $15.5 \%, 18.3 \%$ and $57.9 \%$, respectively. The major SFA were palmitic (C16: 0), stearic (C18:0) and behenic (C22:0) acids. After caning process, the SFA contents varied from 17.4 to $11.0 \%$ with an increase in the duration of cooking. Slightly higher values were noticed in most of the SFA in cooked tuna compared to raw tuna except those cooked for $30 \mathrm{~min}$. However, there were 
significant losses $(\mathrm{p}<0.05)$ in C14:0, C16:0, C18:0 and C22:0 fatty acids in tuna cooked for $30 \mathrm{~min}$. The total MUFA content increased with cooking time from 18.8 to $24.5 \%$. This was mainly due to the increase in C24:1 fatty acid. The PUFA content in cooked tuna was more or less same as that of their raw counterparts. There was no significant decrease $(p>0.05)$ in C20:5 fatty acid, however C22:6 suffered 21\% loss $(p<0.05)$. Losses were significant $(p<0.05)$ with respect to C16:3, C18:2 and C20:2 fatty acids [19]. Czerner, et al. (2015) [11] determined the FAs profile of anchovy (Engraulis anchoita) samples taken during the canning process and also of the covering liquid taken after thermal treatment and observed that Steam-cooking mainly affected the MUFAs and $\omega-6$ fatty acids, whose contents were significantly reduced after this operation (p50.01). This decrease could be related to leaching loss, as shown the reduction of fat content after this step and also to lipid damage due to high temperatures. Selmi, et al. (2007) [3] found that a higher content of C18:1w9 and C18:2w6 fatty acids were found in the canned samples following 3 and 6 months of storage at ambient temperature. Canned sardine and tuna were characterized by their richness in linoleic (10.98-11\%) and oleic (45.3-44.95\%) acids after 3 and 6 months of storage, respectively.

\section{Amino acid}

Protein denaturation by heat does not necessarily cause nutritional loss. However, denatured proteins become more reactive and can be easily damaged by interacting with other constituents. The total free amino acids content decreased during tuna canning, especially if over-processing was employed. Domah, et al. (1984) [23] stated that fresh, canned and cooked, mussels are rich in terms of methionine, lysine, cystine, threonine, tryptophan, phenylalanine, tyrosine and arginine when compared to those of beef or FAO reference protein. Also have found that frying or boiling increases the nutritional value of mussels, as demonstrated by our amino acid composition results. It was also reported that the nutritional value of fried canned mussels was high. The analysis of nitrogen balance of raw or canned tuna protein did not show significant differences between raw and canned tuna in digestibility (DC), biological value (BV) or net protein utilization (NPU). The loss in available lysine in the canned tuna appeared to have no influence on nutritional quality [24]. Heat treatment of canning process may adversely affects the quality of food protein through it influence in the protein contents of the individual amino acids. The general trend that observed was slight decreasing in some amino acids in the canned samples. The loss particularly more observed in histidine which decreased by 16.1 to $17.9 \%$, lysine and arginine also showed a noticed decrease estimated by $4.3-7 \%, 4.4-8.4 \%$ respectively. Sulphur containing amino acids that's is methionine and cystine showed a reduction accounted by $1.9-3.8 \%$ and 20-4.9 \% respectively [5]. Gülgün, et al. (2002) [6] studied the effect of caning process on the smoked mussels of (Mytilus galloprovincialis L) and found that through the smoking and canning processes the relative changes in the content of free amino acids of canned smoked mussels resulted in levels that were reasonably comparable to those of steamed mussels. It's estimated that water conditions where the mussels were cultivated and the additives used for pre-processing before smoking and canning might have been responsible. Glutamic acid content of mussel meat of (Mytilus galloprovincialis $L$ ), before and after canning, was rather high. No negative effects on glutamic acid content due to either smoking or canning were found [6].

\section{Minerals and Vitamins}

Some loss in minerals $(\mathrm{Na}, \mathrm{K}, \mathrm{Mg}, \mathrm{P}, \mathrm{Cu}, \mathrm{Fe}, \mathrm{Ca})$ from the muscle into the dipping medium occurs in canned tuna [25]. Gall, et al. (1983) [26] reported that a high fat content in the flesh produced a low loss in minerals, indicating a kind of interaction between both types of constituents. An advantage of fish canning is that bones become soft textured and thus edible, providing an important calcium source [27]. Mineral content of the raw tuna were $3.65 \pm 0.7$, $124.9 \pm 53.2,116.55 \pm 2.6,1424.75 \pm 3.6,1.55 \pm 0.2,0.65 \pm 0.1,3.2 \pm 50$ and $978.0 \pm 1.0$ for $\mathrm{Ca}, \mathrm{Mg}, \mathrm{Na}, \mathrm{K}, \mathrm{Zn}, \mathrm{Cu}, \mathrm{Fe}$ and $\mathrm{P}$ respectively, while in steamed tuna these values were $3.75 \pm 0.4,95.35 \pm 3.8,114.25 \pm 3.5$, $1082.15 \pm 4.8,1.55 \pm 0.1,0.65 \pm 0.1,2.85 \pm 0.2$ and $835.35 \pm 4.00$ for $\mathrm{Ca}$, $\mathrm{Mg}, \mathrm{Na}, \mathrm{K}, \mathrm{Zn}, \mathrm{Cu}, \mathrm{Fe}$ and P respectively [24]. The heat-labile vitamins thiamine, riboflavin, niacin, pyridoxine and pantothenic acid are the nutrients most damaged by the sterilization process. Varying results have been described for vitamin losses (5-80\% for thiamine; $71-73 \%$ for niacin; $49-50 \%$ for riboflavin) [28].

\section{Histamine}

The histamine compounds are formed from decarboxylation of the amino acid, histidine, through exogenous decarboxylase enzymes that produced by the microorganisms related with fish or environment [29]. Veciana-Nogues, et al. (1997) [30] determined that the contents of histamine (HI) (Micrograms per Gram) throughout Canning Process were $0.32,0.55,0.40,0.54$ and 0.63 for raw fish, before cooking, after cooking, after packing, and end product respectively. The contents of tyramine (TY) (Micrograms per Gram) throughout Canning Process were 0.32, 0.08, 0.24, 0.17 and 0.15 for raw fish, before cooking, after cooking, after packing, and end product respectively [30]. Histamine poisoning caused by the consuming of fish contains high concentrations of histamine in their flesh [31]. FDA has lowered the histamine defect action level from 100 to 50íg/g and has recommended the use of other biogenic amines related with fish spoilage evaluation [32]. Selmi, et al. (2007) [3] Reported that the histamine concentrations increased significantly during storage period but not exceed the acceptable limits. Although tuna and sardine flesh were slightly affected by the canning process, they remained good sources of w3 andw6 fatty acids.

\section{Microbiology}

The Egyptian Organization of Standardizations [33-38] for microbiological aspects of fish products (canned Tuna, canned Sardines, El-Feseekh, salted Sardine, smoked fish and frozen fish), 
stated that these fish products shouldn't have Clostridium. E. coli should be not detect in Salted, smoked and frozen fish. Coliform bacteria in frozen and smoked fish should be less than 103, 101 $\mathrm{CFU} / \mathrm{g}$, respectively. TVC should not exceed 106 and $105 \mathrm{CFU} / \mathrm{g}$ in frozen and smoked fish products, respectively. El-Sherif (2001) [5] found that there was a highly remarkable decrease in the TPC of the tested canned shrimp samples after canning process, Also, the total bacterial counts of canned shrimp with vegetables were higher than those of canned shrimp with tomato sauce, this can be resulted from the spices and some vegetables contaminated with high.

Fatma Arfat (1994) [13] reported that canned sardine and mackerel products were found to be free from anaerobic and aerobic thermophilic bacteria during storage at ambient temperature. Therefore, neither Clostriduim perfringes nor Bacillus cereus were detected in the canned samples even after 24 months storage. Abd El-Ghafour (1999) [15] indicated that the TBC of canned Ti- lapia was gradual increased as the storage period was prolonged. TBC was increased from 0.113 and $0.107 \times 103$ to 0.230 and 0.213 $\times 103$ cells/g of steamed canned Tilapia fillets with using either oil or tomato sauce as filling media while was increased from 0.097 and $0.090 \times 103$ to 0.190 and $0.173 \times 103$ cells/g of fried samples with using the same media through storage at ambient temperature. A high fungi growth was observed in sun dried and smoked chela (Laubuka dadiburjori) after 1 and 2 months of storage compared with canned and frozen chela. This can be from the increasing in water activity and water content [12]. The initial total fungal count of canned chela (Laubuka dadiburjori) was $0.95 \times 102$ (CFU $\mathrm{Gg}^{-1}$ ), these values increased to $1.13 \times 102$ and $2.18 \times 102\left(\mathrm{CFU} \mathrm{Gg}{ }^{-1}\right)$ after 30 and 60 day of storage period respectively. Meanwhile the initial total plate count of canned chela (Laubuka dadiburjori) was increased from $1.44 \times 104\left(\mathrm{CFU} \mathrm{Gg}{ }^{-1}\right.$ ), to $1.88 \times 104$ and $2.57 \times 104$ $\left(\mathrm{CFU} \mathrm{Gg}^{-1}\right.$ ) after 30 and 60 day of storage period respectively [12] (Figure 1).

\section{Canning general process}

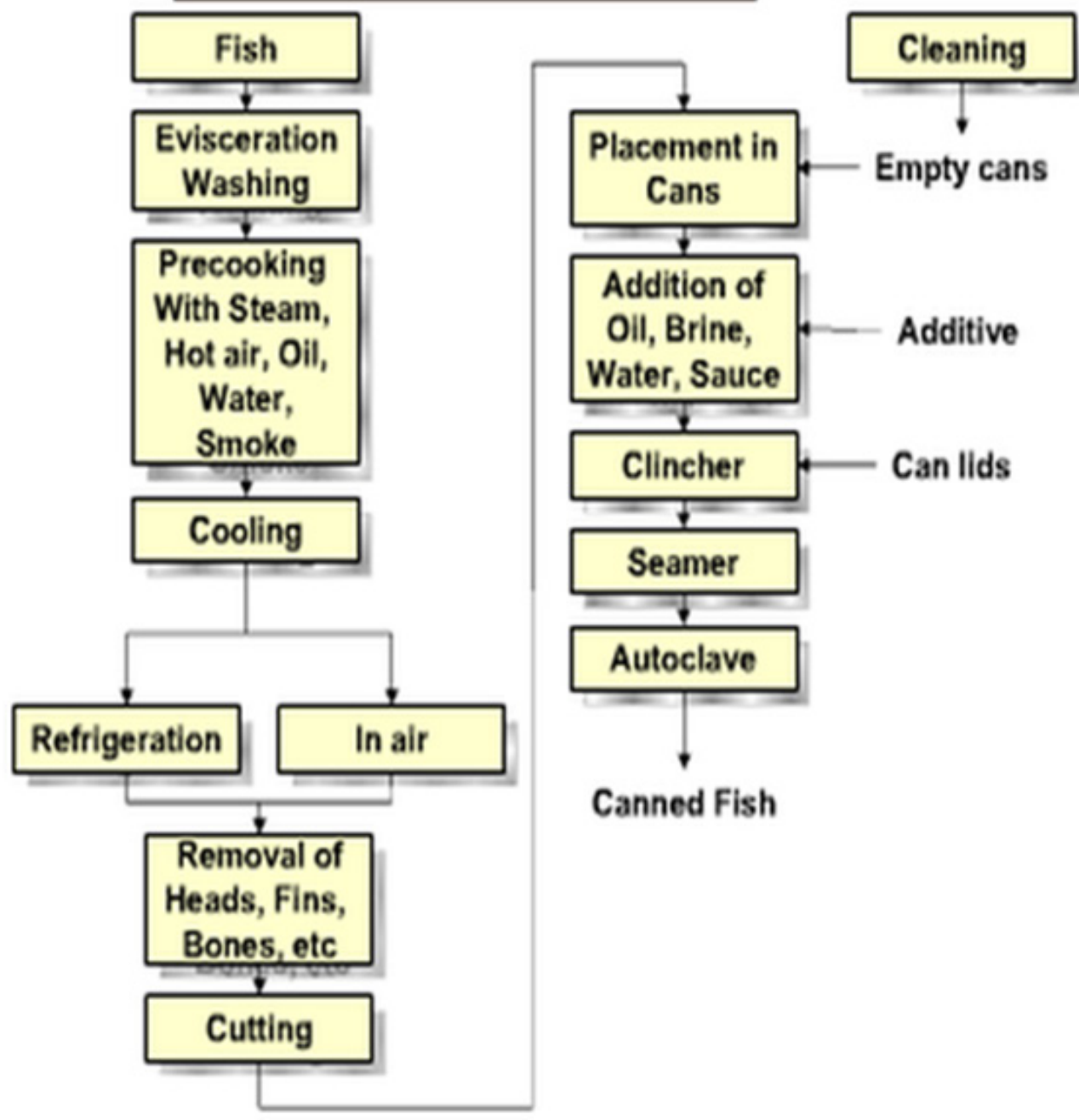

Figure 1: Flow sheet for general canning process. 


\section{Conclusion}

Canned fish products have an economic importance in most countries around the world. During canning process, the bacteria and enzymes inactivated by heat treatment, so the canned fish products have a very long shelf lifetime. Some undesirable effects were occurred during canning process such as loss of essential nutrients, formation of undesirable compounds, browning development and lipid and protein damage which can influence the shelf life of canned products.

\section{Acknowledgement}

None.

\section{Conflict of Interest}

Author declare no conflict of interest.

\section{References}

1. Bratt L (2010) Fish Canning Handbook, Cleeve Prior, Worcester, Blackwell Publishing Ltd, UK.

2. Eyabi GD (1998) Techniques for Fish Handling, Marketing and Smoking in Cameroon. FAO Fisheries Reports 574: 198-206.

3. Selmi S, Monser L and Sadok S (2008) The influence of local canning process and storage on pelagic fish from tunisia: fattyacid profiles and quality indicators. Journal of Food Processing and Preservation 32(3): 443-457.

4. Slabyj BM, Carpenter PN (1977) Processing effect on proximate composition and mineral content of meats of blue mussels (Mytilus edulis). J Food Sci 42: 1153-1155.

5. El Sherif SA (2001) Chemical and technological studies on shrimp and its wastes. Theses Fac, Agric, Fayoum Univ, Egypt.

6. Gülgün FS, Hüseyin G and Hanife K (2002) Determination of the Amino Acid and Chemical Composition of Canned Smoked Mussels (Mytilus galloprovincialis, L.). Turkish Journal of Veterinary and Animal Sciences 32(1): 1-5.

7. Shakila RJ, Jeyasekaran G, Vyla SAP and Saravanakumar R (2005) Effect of delayed processing on changes in histamine and other quality characteristics of 3 commercially canned fishes. J Food Sci 70(1): 24-29.

8. Garcia Arias MT, Pontes EA, Garcia Linares MC, Garcia Fernandez MC and Sanchez Muniz FJ (2003) Cooking-freezing-reheating (CFR) of sardine (Sardina pilchardus) fillets-effect of different cooking and reheating procedures on the proximate and fatty acid compositions. Food Chemistry 83(3): 349-356.

9. Nimish MS, Jeya Shakila R, Jeyasekaran G, Sukumar D (2010) Effect of different types of heat processing on chemical changes in tuna. J Food Sci Technol 47(2): 174-181.

10. El Dengawy, RA El Shehawy, SM Kassem, El Kadi, Zeinab S Farag (2012) Chemical and microbiological evaluation of some fish products samples. J Agric Chem and Biotechn 3(8): 247-259.

11. Czerner M, Agustinelli SP, Guccione S, Yeannes MI (2015) Effect of different preservation processes on chemical composition and fatty acid profile of anchovy (Engraulis anchoita). Int J Food Sci Nutr 66(8): 887894.

12. Sajib Al Reza, Subrata Karmaker, Mahmudul Hasan, Shuvra Roy, Riadul Hoque, et al. (2015) Effect of Traditional Fish Processing Methods on the Proximate and Microbiological Characteristics of Laubuka dadiburjori During Storage at Room Temperature. Journal of Fisheries and Aquatic Science 10(4): 232-243.

13. Fatma AI Arfat (1994) Biochemical and microbiological Studies on canned sardine. Cairo University, Egypt.
14. Ghaly MH (1995) Technological and biochemical studies on some sea food. Suez Canal University, Ismailia, Egypt.

15. Abd El Ghafour SA (1999) Studies on canning of some kinds of Egyptian fish. Thesis Fac Of Agric, Al-Azhar University, Cairo, Egypt.

16. Ibrahim SM (1999) Application of HACCP system in controlling hazards of some fish products. Ain Shams University, Cairo, Egypt.

17. Yeannes M, del Valle C and Lupin H (1983) Generación de bases nitrogenadas volátiles durante el proceso de elaboración de conservas de pescado. Revista de Agroquímica y Tecnología de Alimentos 23: 585590.

18. Aubourg S, Gallardo J, Medina I (1997) Changes in lipids during different sterilizing conditions of albacore tuna (Thunnus alalunga) canning. International Journal of Food Science and Technology 32: 427-432.

19. Chia SS, Baker RC, Hotchkiss JH (1983) Quality comparison of thermo processed fishery products in cans and retortable paunches. Journal of Food Science 48(5): 1521-1525.

20. Pikul J, Leszezynski DE, Kummerow FA (1984) Relative role of phospholipids, vtriacylglycerols and cholesterol esters on malonaldehyde formation in fat extracted from chicken meat. J Food Sci 49: 704-708.

21. Koizumi C, Wada S and Ohshima T (1987) Factors affecting development of rancid off odor in cooked fish meats during storage at $5^{\circ} \mathrm{C}$. Nippon Suisan Gakkaishi 53(11): 2003-2009.

22. Maeda Y, Ishikawa M, Yamamoto M, Terada S, Masui T, et al. (1985) Effect on cooking on contents of fatty acids, specially eicosapentaenoic acid (20:5) and docosahexaenoic acid (22:6) in sardine. J Jpn SOC Nutr Food Sci 38: 447-450.

23. Domah MB, Hussein MA, El Dashlouty AA, El Sherif MSA (1984) Amino acid composition of fresh and processed Egyptian mussels. J Food Sci 12: 77-83.

24. Castrillo MA, Pilar Navarro M, Garcia Arias MT (1996) Tuna Protein Nutritional Quality Changes after Canning. Journal of food science 61(6): 1250-1253.

25. Seet S and Brown D (1983) Nutritional quality of raw, precooked and canned albacore tuna (Thunnus alalunga). Journal of Food Science 48 : 288-289.

26. Gall K, Otwell W, Korurger J, Appledorf H (1983) Effects of four cooking methods on the proximate, mineral and fatty acid composition of fish fillets. Journal of Food Science 48: 1068-1074.

27. March B (1982) Effect of processing on nutritive value of food: Fish FL: CRC Press, In: Rechcigl Jr M (ed.) Handbook of Nutritive Value of Processed Food. Boca Raton, Florida, pp. 363-381.

28. Banga J, Alonso A, Gallardo J, Pérez Martín R (1993) Kinetics of thermal degradation of thiamine and surface colour in canned tuna. Z Lebensm Unters Forsch 197(2): 127-131.

29. Rawles DD, Flick GJ, Martin RE (1996) Biogenic amines in fish and shellfish. Advances in Food and Nutrition Research 39: 329-364.

30. Veciana Nogues MT, Marine Font A and Vidal Carou MC (1997) Biogenic Amines in Fresh and Canned Tuna. Effects of Canning on Biogenic Amine Contents. Journal of Agricultural and Food Chemistry 45(11): 43244328 .

31. Taylor SL (1986) Histamine food poisoning: Toxicology and clinical aspects. Crit Rev Toxicol 17(2): 91-128.

32. FDA (1995) Decomposition and histamines Raw, Frozen Tuna and MahiMahi; Canned Tuna; and Related Species. Revised Compilance Policy Guide 149: 39754-39756.

33. EOS Egyptian Organization for Standardization (2005a) Canned Tuna and Bonito. Egyptian Organization for Standardization and Quality, Arab Republic of Egypt, p. 804.

34.EOS Egyptian Organization for Standardization (2005b) Canned Sardines Egyptian Organization for Standardization and Quality, Arab Republic of Egypt, p. 287. 
35. EOS Egyptian Organization for Standardization (2005c) Salted Fish Part: 1 Fesiekh, Egyptian Organization for Standardization and Quality, Arab Republic of Egypt, pp. 1725-1731.

36. EOS Egyptian Organization for Standardization (2005d) Salted Fish, Part: 2 Salted Sardine, Egyptian Organization for Standardization and Quality, Arab Republic of Egypt, pp. 1725-1732.
37. EOS Egyptian Organization for Standardization (2005e) Smoked Fish, Egyptian Organization for Standardization and Quality, Arab Republic of Egypt, p. 288.

38. EOS Egyptian Organization for Standardization (2009) Frozen Fish, Part: 1 Whole Fish, Egyptian Organization for Standardization and Quality, Arab Republic of Egypt, pp. 889-891. 